\title{
Plasmids and Insecticidal Activity of Delta-endotoxin Crystals from Bacillus thuringiensis var. israelensis
}

\author{
Michio Himeno, Masao Ikeda, Kikuo Sen, Naoto Koyama, \\ Tohru Komano, Haruyasu Yamamoto* \\ and Isamu NAKAYAMA* \\ Laboratory of Biochemistry, Department of Agricultural Chemistry, \\ Kyoto University, Kyoto 606, Japan \\ *Sumitomo Chemical Co., Ltd., Takarazuka Research Center, \\ Takatsukasa 4-chome, Takarazuka, Hyogo 665, Japan \\ Received February 13, 1984
}

\begin{abstract}
The insecticidal activities of 12 strains of Bacillus thuringiensis var. israelensis and purified delta-endotoxin crystals from the $4 \mathrm{Q} 1$ strain against mosquito larvae, Culex pipiens pallens, were measured and then compared with those of $B$. thuringiensis var. kurstaki and Bacillus sphaericus. Plasmid DNAs in acrystalliferous or crystalliferous strains of those bacteria and varieties were isolated and analyzed by agarose gel electrophoresis. There were at least 7 plasmids in the $4 \mathrm{Q} 1$ strain.

To determine the specific plasmid coding the mosquito-toxic endotoxin protein, the relationship between the activities and the plasmid patterns of those strains was investigated. The strains harboring the plasmid pBTI-6 NDA (70 megadaltons) had insecticidal activity even though they were acrystalliferous mutants, but all strains lacking the plasmid pBTI-6 DNA did not have the activity.
\end{abstract}

Bacillus thuringiensis var. israelensis (serotype $\mathrm{H} 14$ ) is kown as a bacterial pathogen against mosquito ${ }^{1)}$ and black fly $^{2)}$ larvae. A parasporal body is called a proteinous crystalline inclusion, delta-endotoxin erystal, or simply the crystal, which is produced in the sporulating cells of $B$. thuringiensis and this crystal is only composed of the toxin protein. ${ }^{3)}$ A few cultures of $B$. thuringiensis are used as commercial insecticidal formulations, because the crystals of $B$. thuringiensis var. kurstaki and several other varieties are toxic to many lepidopteran insects and that of $B$. thuringiensis var. israelensis ${ }^{4,5)}$ is toxic to dipteran insects. It was reported that the molecular weight of lepidopterous toxic protein was about 68,000 but that of dipteran toxic protein was 26,000 . The antiserum against the lepidopterous toxic protein did not react with the dipteran toxin and also the antiserum against dipteran toxic protein did not react with the lepidopterous toxin. ${ }^{3)}$
Recently, it was suggested that the deltaendotoxin protein gene might be encoded in a specific plasmid as shown by curing experiments, ${ }^{6.7)}$ when the lepidopterous toxic strains were used, in which the loss of the crystal formation was associated with the loss of the specific plasmid. When a certain plasmid was transferred into an acrystalliferous strain of $B$. thuringiensis or Bacillus cereus, these strains were transformed into crystal-forming strains. $^{8)}$ The delta-endotoxin protein genes from four strains, B. thuringiensis var. kurstaki HD1-Dipel, ${ }^{9)}$ kurstaki, ${ }^{10)}$ berliner $1715^{11)}$ and kurstaki HD73, ${ }^{12)}$ carrying strong insecticidal activity against lepidopterous insects, were cloned in a strain of Escherichia coli. The homolegous region to the cloned deltaendotoxin protein gene ${ }^{13)}$ was distributed on plasmids or on chromosomal DNA in various varieties except israelensis, kyushuensis, indiana, and dakota. The nucleotide sequence of the promoter region and part of the 
coding region of the delta-endotoxin protein gene cloned from the plasmids in the HD1Dipel strain were determined ${ }^{14)}$ and the sequence of the promoter region of the crystal protein gene cloned from chromosomal DNA of the berliner 1715 was also determined. ${ }^{15}$ )

On the other hand, it was suggested that the delta-endotoxin protein gene of the israelensis strain was encoded on a high molecular weight plasmid of a indeterminate size (Kamdar and Jayaraman $\left.^{16)}\right)$, on a 72 megadaltons $(\mathrm{Md})$ plasmid in 9 plasmids (Ward and Ellar ${ }^{17)}$ ), and on a small plasmid $(4.0 \sim 4.4 \mathrm{Md})$ in 3 plasmids (Faust et al. ${ }^{18)}$ ). However, the relationship between the insecticidal activities and the plasmid patterns of those strains was not clear.

In this paper, the plasmids in 12 strains of israelensis, the derivatives from the 4Q1 strain, 2 strains of kurstaki, and 3 strains of $B$. sphaericus were isolated and were analyzed by agarose gel electrophoresis. The insecticidal activities of these strains were measured against mosquito larvae. It is concluded that a $70 \mathrm{Md}$ plasmid in the israelensis strains is associated with the ability to produce the delta-endotoxin protein.

\section{MATERIALS AND METHODS}

Strains and mediums. Table I shows bacterial species, strains, varieties, and sources of bacteria used in this study. Bacillus thuringiensis and Bacillus sphaericus were cultured in PY broth medium ${ }^{19)}$ (polypeptone $10 \mathrm{~g}$, yeast extract $5 \mathrm{~g}, \mathrm{NaCl} 5 \mathrm{~g}$ per liter, $\mathrm{pH} 7.0$ ) or GNB broth medium $^{20)}$ [polypeptone $10 \mathrm{~g}$, beef extract (dry powder) $5 \mathrm{~g}$, glucose $1 \mathrm{~g}, \mathrm{NaCl} 2 \mathrm{~g}$ per liter, $\mathrm{pH} 7.0$ ] at $30^{\circ} \mathrm{C} . B$. subtilis was grown in Pennassay broth medium (Difco $\mathrm{Lab}$.) or PY broth medium at $37^{\circ} \mathrm{C}$ for isolation of standard plasmid DNA. Escherichia coli was cultured in L broth medium at $37^{\circ} \mathrm{C}$ overnight. The Bacillus strains were grown on a GNB agar plate composed of GNB broth medium containing $1.5 \%$ agar (GNB agar medium) for $7 \sim 8$ days at $30^{\circ} \mathrm{C}$, and then formation of the deltaendotoxin crystal in the Bacillus strains was observed with phase-contrast microscopy.

The israelensis strains [4Q1 and ONR60A (IPL)] were treated with $N$-methyl- $N{ }^{\prime}$-nitro- $N$-nitrosoguanidine (NTG) $(0.005 \sim 0.01 \%)$ by the procedures described Nishiitsutsuji-Uwo et al., ${ }^{20)}$ and the cells were cultured on GNB agar plates containing $50 \mu \mathrm{g} / \mathrm{ml}$ of rifampicin. Subsequently asporogenic mutants in the rifampicin- resistant cells were selected by the method described Nishiitsutsuji-Uwo et al. ${ }^{20)}$

Purification of delta-endotoxin crystals. An inoculum of B. thuringiensis var. israelensis $4 \mathrm{Q} 1$ strain was spread on 4 GNB agar plates $(35 \times 35 \mathrm{~cm})$ by a glass spreader and incubated at $28^{\circ} \mathrm{C}$ for 7 days. Sporangia containing spores and the endotoxin crystals were disrupted with an ultrasonic oscillator (Ultrasonic Generator 4280, Kaijo Denki Co., Ltd.) for 10-min intervals in an ice-bath. The disrupted cells were suspended in water and centrifuged at $15,000 \times g$ for $15 \mathrm{~min}$ at $4^{\circ} \mathrm{C}$. The delta-endotoxin crystals in the pellets were separated and purified by the biphasic separation technique described by Goodman et al., ${ }^{21)}$ and this procedure was repeated $8 \sim 10$ times. The deltaendotoxin crystals were washed with distilled water several times and centrifuged at $15,000 \times g$ for $15 \mathrm{~min}$, and finally $85 \mathrm{mg}$ of purified dry crystals were obtained after lyophilization.

Preparation of crude sample to determine the insecticidal activity against mosquito larvae. B. thuringiensis strains for assay of the insecticidal activity against mosquito larvae were grown in $100 \mathrm{ml}$ of GNB broth medium at $28^{\circ} \mathrm{C}$ for $7 \sim 8$ days with vigorous shaking. The cells were centrifuged at $12,000 \times g$ for $30 \mathrm{~min}$ and then suspended in $10 \mathrm{ml}$ of distilled water. The suspensions were frozen in dry ice-ethanol and thawed three times and subsequently homogenized with an ultrasonic oscillator (Handy Sonic, model UR-20p, Tomy Seiko Co., Ltd.) for 5 min at 1-min intervals in an ice-bath. The disrupted cell suspensions were centrifuged at $12,000 \times g$ for $30 \mathrm{~min}$ at $4^{\circ} \mathrm{C}$. The pellets were suspended in $3 \mathrm{ml}$ of distilled water. Just before use for assay of $\mathrm{LC}_{50}$ the pellets were homogenized with the ultrasonic oscillator again. Asporogenic mutants of the $4 \mathrm{Q} 1$ strain and the B. sphaericus strains were cultured in $100 \mathrm{ml}$ of GNB broth medium as described above. After harvesting the cells, they were suspended in $3 \mathrm{ml}$ of distilled water and subsequently disrupted by freezing and thawing, and homogenized with the ultrasonic oscillator. The suspensions of disrupted cells were directly used for the assay of $\mathrm{LC}_{50}$ after homogenization with the oscillator. The dry weights of the usual crude sample extracted from the $4 \mathrm{Q} 1$ strain and the asporogenic mutants were $13.3 \sim 18.7 \mathrm{mg} / \mathrm{ml}$.

Assay of insecticidal activity. Mosquito larvae, Culex pipiens pallens Coquillett, used in this experiment were reared in this laboratory (Sumitomo Chemical Co., Ltd.) with an artificial diet containing a mixture $(1: 1)$ of finely ground rabbit chow and dry brewers' yeast at $27^{\circ} \mathrm{C}$. The insecticidal activities were measured in duplicate and 20 third-instar larvae were placed in a cup containing $100 \mathrm{ml}$ of distilled water adding the serial dilution of the purified delta-endotoxin crystals or crude samples. The cups holding larvae were maintained with a photoperiod of $16 \mathrm{hr}$ of light and $8 \mathrm{hr}$ of darkness at $25^{\circ} \mathrm{C}$ for 3 days. Mortalities were counted at $24 \mathrm{hr}$ or/and $48 \mathrm{hr}$ and lethal concentration $\left(\mathrm{LC}_{50}\right)$ values were expressed as $\mathrm{ppm}(\mathrm{w} / \mathrm{w})$ re- 
Table I. Bacterial Strains Used in Determination of the Insecticidal

ACTIVITY AND/OR IsOlation OF PlaSmid DNA

\begin{tabular}{|c|c|c|}
\hline Species & Strain name ${ }^{a}$ & Source and reference \\
\hline Bacillus thuringiensis var. israelensis & $\begin{array}{l}\text { HD500 } \\
\text { HD500A } \\
\text { HD500B } \\
\text { HD522 } \\
\text { HD563 } \\
\text { HD567 } \\
\text { HD648 } \\
\text { HD654 } \\
\text { HD756 } \\
\text { 4Q1 } \\
\text { 4Q4 } \\
\text { ONR60A (Bulla) } \\
\text { ONR60A (IPL) } \\
\text { 4Q1-54 }\end{array}$ & $\begin{array}{l}\text { USDA }^{b} \text { and } \text { ARM }^{c} \\
\text { This work } \\
\text { This work } \\
\text { USDA and ARM } \\
\text { USDA and ARM } \\
\text { USDA and ARM } \\
\text { USDA and ARM } \\
\text { USDA and ARM } \\
\text { USDA and ARM } \\
\text { BGSC and (ONR60A) in BGSC catalog } \\
\text { BGSC and (HD657) })^{d} \text { in BGSC catalog } \\
\text { T. Iizuka } \\
\text { T. Iizuka } \\
\text { This work }\end{array}$ \\
\hline Bacillus thuringiensis var. kurstaki & $\begin{array}{l}\text { HD1 } \\
4 \mathrm{D} 1\end{array}$ & $\begin{array}{l}\text { USDA and ARM } \\
\text { BGSC and (HD1) in BGSC catalog }\end{array}$ \\
\hline \multirow{2}{*}{$\begin{array}{l}\text { Bacillus thuringiensis var. thuringiensis } \\
\text { Bacillus sphaericus }\end{array}$} & $\mathrm{HD} 2$ & USDA and ARM \\
\hline & $\begin{array}{l}13 \mathrm{~A} 1 \\
2297 \\
\text { SSII-1 }\end{array}$ & $\begin{array}{l}\text { USDA and }(1593)^{d} \text { in BGSC catalog } \\
\text { Y. Izumi }{ }^{g} \\
\text { Y. Izumi }\end{array}$ \\
\hline Bacillus subtilis 168 & $\begin{array}{l}1 \mathrm{E} 6 \\
1 \mathrm{E} 21 \\
1 \mathrm{E} 24 \\
1 \mathrm{E} 25 \\
1 \mathrm{E} 27\end{array}$ & $\begin{array}{l}\text { BGSC and BGSC catalog, harboring pUB110 } \\
\text { BGSC and BGSC catalog, harboring pBD8 } \\
\text { BGSC and BGSC catalog, harboring pBD10 } \\
\text { BGSC and BGSC catalog, harboring pBD11 } \\
\text { BGSC and BGSC catalog, harboring pBD9 }\end{array}$ \\
\hline Escherichia coli & $\begin{array}{l}\mathrm{C} 600 \\
459\end{array}$ & $\begin{array}{l}\text { T. Uozumi },{ }^{h} \text { harboring pTA } 1302 \\
\text { W. Goebel, }{ }^{i} \text { harboring pJK } 3\end{array}$ \\
\hline $\begin{array}{cl}a & \text { Strain name was shown by HD nu } \\
& \text { in BGSC catalog or original nan } \\
b & \text { Provided by Dr. T. Yamamoto, } \\
c & \text { ARM; US Department of Agri } \\
& \text { October, 1982. } \\
{ }_{d} & \text { (ONR60A), (HD657), (HD1) an } \\
e & \text { BGSC; The Bacillus Genetic Sto } \\
f & \text { Provided by Dr. T. Iizuka, Hokk } \\
g & \text { Provided by Dr. Y. Izumi, Kyoto } \\
& \text { State Univ., U.S.A. } \\
{ }_{h} & \text { Provided by Dr. T. Uozumi, the } \\
& \\
& \text { Provided by Dr. W. Goebel, Un }\end{array}$ & $\begin{array}{l}\text { (Dulmage culture } \\
\text { on Insect Research, } \\
\text { dre Research Servic } \\
\text { 93) are written as c } \\
\text { enter, Catalog of S } \\
\text { Univ., Japan. } \\
\text { v., Japan, who origi } \\
\text { v. of Tokyo, Japan. } \\
\text { Jürzburg, West Ger }\end{array}$ & $\begin{array}{l}\text { number described in ARM), BGSC number described } \\
\text { ARS, USDA, U.S.A. } \\
\text { ce. Agricultural Reviews and Manuals. ARM-S-30/ } \\
\text { original code in the catalog. } \\
\text { trains, The Ohio Univ., U.S.A. } \\
\text { inally obtained it from Dr. E. W. Davidson, }{ }^{30)} \text { Arizona } \\
\text { rmany. }\end{array}$ \\
\hline
\end{tabular}

quired to cause $50 \%$ mortality of the larvae. An average of the two experiments is shown in Table II.

Isolation of plasmid DNA. The basic procedure used for extraction of small plasmid DNA $(<10 \mathrm{Md})$ followed the procedure described by Davis et al., ${ }^{22)}$ and for large plasmids followed the procedure described by Birnboim and Doly. ${ }^{23)}$ Plasmids pUB110 (3.0 Md), ${ }^{24)}$ pBD8 (6.0 Md), pBD9 (5.4Md), pBD10 (4.4 Md), pBD11
(4.0 Md), pTA1302 (5.2 Md), and pJK3 $(7.6 \mathrm{Md})^{25)}$ were isolated from B. subtilis 168 strains (1E6, 1E21, 1E27, $1 \mathrm{E} 24$, and 1E25), E. coli $\mathrm{C} 600$, and $E$. coli 459 , respectively. Total plasmid DNAs of $B$. thuringiensis HD1 and HD2 strains were also used as plasmid DNA markers. ${ }^{7)}$

Agarose gel electrophoresis. Agarose gel electrophoresis was performed in Dotite agarose II (Dojindo Lab., 
Kumamoto, Japan) at a concentration of $0.4 \sim 0.7 \%$ containing ethidium bromide $(\mathrm{EtBr})(1 \mu \mathrm{g} / \mathrm{ml})$ using a horizontal apparatus $\left(15 \times 20 \times 0.4 \mathrm{~cm}^{3}\right)$. Electrophoretic migration was done out at $40 \mathrm{~V}$ for $1 \mathrm{hr}$ and then at $100 \mathrm{~V}$ for $4 \mathrm{hr}$ in Tris-acetate buffer ( $2 \mathrm{~mm}$ EDTA, $40 \mathrm{~mm}$ Tris, $20 \mathrm{~mm} \mathrm{CH} \mathrm{CH}_{3} \mathrm{COONa}$, pH 7.4) containing $\mathrm{EtBr}$, one quarter volume of the dye mixture $(0.1 \%$ bromphenol blue, $50 \%$ sucrose, $1 \mathrm{~mm}$ EDTA) was added to the plasmid sample prior to loading and $15 \sim 25 \mu \mathrm{l}$ of the sample was applied into a well. Plasmid DNA was visualised by illumination with a UV $\operatorname{lamp}(\lambda=2536 \AA)$ and photographed with a Mamiya RB67 camera (Polaroid type 665 positive/negative film) using a red filter.

Two-dimensional gel electrophoresis for determination of covalently closed circular (ccc), open circular (oc), or linear (l) DNA in plasmid DNA samples was by a modified technique of Hintermann et al. ${ }^{26)}$ Sample $\{40 \mu \mathrm{l}$ of DNA sample [4Q1 or ONR60A (IPL)]\} were first run on $0.5 \%$ agarose gel in one direction at $40 \mathrm{~V}$ for $30 \mathrm{~min}$, and then at $3 \mathrm{~V} / \mathrm{cm}$ for $4 \mathrm{hr}$ in the Tris-acetate buffer containing EtBr. The gel was exposed to UV light $(15 \mathrm{~W}$ Toshiba germicidal lamp at a height of $30 \mathrm{~cm}$ ). The agarose gel was then turned $90^{\circ}$ and run as described above. Before detection of plasmid bands the gel was then soaked in the electrophoresis buffer containing $2 \mu \mathrm{g} / \mathrm{ml}$ of EtBr for $30 \mathrm{~min}$.

Reagents and enzymes. Yeast extract, Pennassay broth, and Bacto-tryptone were purchased from Difco Lab. Lysozyme, RNase A, and SDS were from Sigma Chemical

Table II. $\quad$ LC $_{50}$ OF 13 Strains of Bacillus thuringiensis and 3 Strains of Bacillus sphaericus to Mosquito LaRvaE

\begin{tabular}{|c|c|c|c|c|c|c|}
\hline \multirow{2}{*}{ Species } & \multirow{2}{*}{ Strain } & \multirow{2}{*}{ Exp. ${ }^{a}$} & \multicolumn{4}{|c|}{$\mathrm{LC}_{50}(\mathrm{ppm})^{b}$} \\
\hline & & & \multicolumn{2}{|c|}{ At $24 \mathrm{hr}$} & \multicolumn{2}{|c|}{ At $48 \mathrm{hr}$} \\
\hline \multirow{16}{*}{$\begin{array}{l}\text { B. thuringiensis } \\
\text { var. israelensis }\end{array}$} & $4 \mathrm{Q} 1^{d}$ (purified) & 1 & 0.0060 & $(0.0032 \sim 0.010)^{c}$ & 0.0050 & $(0.0028 \sim 0.0093)$ \\
\hline & 4Q1 & 1 & 2.0 & $(1.1 \sim 3.7)$ & 1.6 & $(1.0 \sim 3.4)$ \\
\hline & $4 \mathrm{Q} 1$ & 2 & 2.1 & $(1.7 \sim 2.7)$ & 1.3 & $(1.1 \sim 1.6)$ \\
\hline & HD500 & 2 & 5.8 & $(2.8 \sim 9.2)$ & 3.6 & $(2.2 \sim 6.1)$ \\
\hline & HD522 & 2 & 0.31 & $(0.25 \sim 0.37)$ & 0.25 & $(0.19 \sim 0.32)$ \\
\hline & HD563 & 2 & 1.0 & $(0.87 \sim 1.1)$ & 0.68 & $(0.47 \sim 1.2)$ \\
\hline & HD567 & 2 & $>100$ & & $>100$ & \\
\hline & HD648 & 2 & 9.4 & $(7.2 \sim 13)$ & 4.5 & $(3.4 \sim 5.9)$ \\
\hline & HD654 & 2 & 0.50 & $(0.43 \sim 0.60)$ & 0.47 & $(0.40 \sim 0.56)$ \\
\hline & HD756 & 2 & $>100$ & & $>100$ & \\
\hline & ONR60A (Bulla) & 2 & 12 & $(9.4 \sim 15)$ & 7.4 & $(6.0 \sim 9.0)$ \\
\hline & ONR60A (IPL) & 2 & $>100$ & & $>100$ & \\
\hline & ONR60A (IPL) & 3 & & & $>1,000$ & \\
\hline & 4Q4 & 3 & & & $>1,000$ & \\
\hline & 4Q1 & 4 & & & 0.21 & $(0.07 \sim 0.59)$ \\
\hline & $4 \mathrm{Q} 1-54^{e}$ & 4 & & & $\doteqdot 60$ & \\
\hline \multirow{2}{*}{$\begin{array}{l}\text { B. thuringiensis } \\
\text { var. kurstaki }\end{array}$} & HD1 & 2 & $>100$ & & $>100$ & \\
\hline & 4D1 & 4 & & & $\doteqdot 400$ & \\
\hline \multirow{3}{*}{ B. sphaericus } & $13 \mathrm{~A} 1$ & 2 & $10 \sim 100$ & & $10 \sim 100$ & \\
\hline & 2297 & 2 & $>100$ & & $10 \sim 100$ & \\
\hline & SSII-1 & 2 & $>100$ & & $>100$ & \\
\hline
\end{tabular}

a Experimental number.

${ }_{b} \quad \mathrm{LC}_{50}$; lethal concentration ( $50 \%$ endpoint) is shown by ppm (w/w). Twenty larvae (3rd instar) of Culex pipiens pallens were bred in $100 \mathrm{ml}$ of water at $25^{\circ} \mathrm{C}$ for 3 days and the average of dual experiments at $24 \mathrm{hr}$ or/and $48 \mathrm{hr}$ are shown in the table. The detail procedures for determination were described in MATERIALS AND METHODS.

c Numbers within parentheses are $95 \%$ confidence limit.

d 4Q1 (purified) shows purified 4Q1 crystals. B. thuringiensis 4Q1 was cultured on the GNB plates described in MATERIALS AND METHODS. The crystals were purified by the biphasic separation technique. Lyophilized crystals were suspended in water and used.

e Sporeless and rifampicin-resistant $(50 \mu \mathrm{g} / \mathrm{ml})$ mutant of $4 \mathrm{Q} 1$, which was treated $N$-methyl- $N^{\prime}$-nitro- $N$ nitrosoguanidine $(0.005 \%)$ for selection of mutants lacking in ability to form a spore, did not produce the deltaendotoxin crystals during 8 days at $28^{\circ} \mathrm{C}$. 
Co. Polyethylene glycol 6,000, dextran sulfate 500, $\mathrm{CsCl}$, EtBr, tris(hydroxymethyl)aminomethane, and other chemicals were bought from Nakarai Chemicals, Ltd.

\section{RESULTS}

Insecticidal activity of purified $4 Q 1$ crystals and its crude sample

The $\mathrm{LC}_{50}$ value of purified delta-endotoxin crystals isolated from $B$. thuringiensis var. israelensis 4Q1 strain was determined with mosquito larvae and the results are shown in Table II (Exp. 1). The insecticidal activity of the purified crystals was $0.006 \mathrm{ppm}$ at $24 \mathrm{hr}$. This $\mathrm{LC}_{50}$ value of the crystals corresponded to $6 \mathrm{ng} / \mathrm{ml}$ at $24 \mathrm{hr}$ and this is a very much lower value than that described by Kamadar and Jayaraman ${ }^{16)}$ but higher than that by Tyrell et $a l{ }^{4)}$ On the other hand, in the same experiment the $\mathrm{LC}_{50}$ of the crude sample was $2.0 \mathrm{ppm}$.

\section{Insecticidal activities of crude samples from various strains}

To determine the insecticidal activity against mosquito larvae, crude samples were prepared from $100 \mathrm{ml}$ cultures and the $\mathrm{LC}_{50}$ values were determined. These results are also shown in Table II (Exp. 2, 3, and 4). The order of their activities is as follows; HD522 $>$ HD654 $>$ HD 563 $>4$ Q $1>$ HD500 $>$ HD648 $>$ ONR60A (Bulla) $>>$ HD567, HD756, ONR60A (IPL). ONR60A (IPL), HD567, and HD756 did not have any insecticidal activity against mosquitoes. Yamamoto and McLaughlin, ${ }^{27)}$ and other investigatiors ${ }^{28)}$ showed that the HD1 strain had activity against mosquito larvae but the $\mathrm{LC}_{50}$ value of the HD1 strain which was described as 4D1 strain in the catalog of strains of Bacillus Genetic Stock Center was $400 \mathrm{ppm}$ at $48 \mathrm{hr}$. This value is much higher than that of other active strains, for example, 4Q1 or HD522. Several investigators showed that $B$. sphaericus ${ }^{30)}$ strains also had insecticidal activities against mosquito larvae. Because the $\mathrm{LC}_{50}$ values of the three strains of $B$. sphaericus were $10 \sim 100 \mathrm{ppm}$ or over $100 \mathrm{ppm}$, the insecticidal activity of $B$. sphaericus against mosquito larvae was higher than that of the 4D1 strain. Ten asporogenic mutants were obtained from about 300 rifampicin-resistant mutants derived from the 4Q1 strain with mutagen (NTG) treatment, and all of these mutants have lost both the delta-endotoxin crystal- and spore-forming abilities. However, the $\mathrm{LC}_{50}$ value of an asporogenic mutant 4Q1-54 was about $60 \mathrm{ppm}$ and this value is lower than that of ONR60A (IPL), 4Q4, HD1 and the B. sphaericus strains. The $\mathrm{LC}_{50}$ values of other mutants which lost both the crystal- and spore-forming abilities were $190 \sim 480 \mathrm{ppm}$ (data not shown in Table II) and almost the same as that of 4D1 strain.

Agarose gel electrophoretic pattern of B. thuringiensis var. israelensis $4 Q 1$ strain

Agarose gel electrophoresis of plasmid

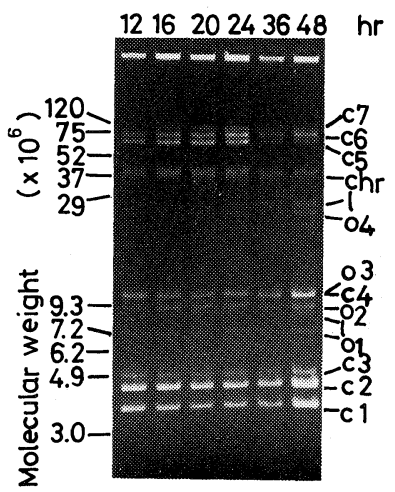

FIG. 1. Plasmid Patterns of B. thuringiensis var. israelensis (4Q1 Strain).

The 4Q1 cells in PY broth medium were harvested at various times after inoculation and the plasmid DNAs prepared by a modification of the procedure described by Birnboim and Doly ${ }^{23}$ were electrophoresed on $0.5 \%$ agarose horizontal slab gel at $40 \mathrm{~V}$ for $1 \mathrm{hr}$, then at $100 \mathrm{~V}$ for $4 \mathrm{hr}$. The configuration of plasmids was determined by two-dimensional electrophoresis by the procedure described in Materials AND Methods. The molecular weights of the previously characterized ccc plasmids from HD1, HD2, and several bacteria harboring marker plasmids are listed on the left margin of the photograph as size references. Chromosomal DNA, ccc, oc, and linear plasmid DNAs are indicated by chr, c, o, and 1, respectively, on the right margin. The numbers $(1 \sim 7)$ beside $\mathrm{c}$ or $\mathrm{o}$ indicate pBTI-1, pBTI-2, pBTI-3, pBTI-4, pBTI-5, pBTI-6 and $\mathrm{pBTI}-7$, respectively. The numbers above gel lane show the time (hr) after inoculation. 
Table III. Number and Size of Plasmid DNA Detected in Crystalliferous and ACRYSTALliferous StRaINS OF B. thuringiensis AND B. sphaericus

\begin{tabular}{|c|c|c|c|c|c|c|c|c|c|c|}
\hline \multirow[b]{2}{*}{ Species } & \multirow[b]{2}{*}{ Strain } & \multirow[b]{2}{*}{ Crystal } & \multirow{2}{*}{$\begin{array}{l}\text { No. of } \\
\text { plasmids }\end{array}$} & \multicolumn{7}{|c|}{ Plasmid DNA (Megadaltons) } \\
\hline & & & & $\begin{array}{c}3.6 \\
\text { pBTI-1 }\end{array}$ & $\begin{array}{c}4.3 \\
\text { pBTI-2 }\end{array}$ & $\begin{array}{c}4.9 \\
\text { pBTI-3 }\end{array}$ & $\begin{array}{c}10.0 \\
\text { pBTI-4 }\end{array}$ & $\begin{array}{c}63 \\
\text { pBTI-5 }\end{array}$ & $\begin{array}{c}70 \\
\text { pBTI-6 }\end{array}$ & $\begin{array}{c}82 \\
\text { pBTI-7 }\end{array}$ \\
\hline \multirow{13}{*}{$\begin{array}{l}\text { B. thuringiensis } \\
\text { var. israelensis }\end{array}$} & $\mathrm{HD}^{2} 00 \mathrm{~A}^{a}$ & + & 6 & + & + & - & + & + & + & + \\
\hline & HD500B & - & 5 & + & + & - & + & + & - & + \\
\hline & HD522 & + & 5 & - & + & + & - & + & + & + \\
\hline & HD563 & + & 7 & + & + & + & + & + & + & + \\
\hline & HD567 & - & 6 & + & + & + & + & + & - & + \\
\hline & HD648 & + & 7 & + & + & + & + & + & + & + \\
\hline & HD654 & + & 7 & + & + & + & + & + & + & + \\
\hline & HD756 & - & 6 & + & + & + & + & + & - & + \\
\hline & 4Q1 & + & 7 & + & + & + & + & + & + & + \\
\hline & $4 \mathrm{Q} 1-54^{b}$ & - & 5 & - & + & + & + & + & + & - \\
\hline & 4Q4 & - & 4 & + & + & - & - & + & - & + \\
\hline & $\begin{array}{l}\text { ONR60A } \\
\text { (Bulla) }\end{array}$ & + & 5 & + & + & - & - & + & + & + \\
\hline & $\begin{array}{l}\text { ONR60A } \\
\quad \text { (IPL) }\end{array}$ & - & 5 & + & + & - & + & + & - & + \\
\hline $\begin{array}{l}\text { B. thuringiensis } \\
\text { var. kurstaki }\end{array}$ & HD1 & + & 10 & \multicolumn{7}{|c|}{$1.4,4.9,5.2,5.4,9.3,29,44,52,(110),^{c}(120)$} \\
\hline \multirow[t]{2}{*}{$\begin{array}{l}\text { B. thuringiensis } \\
\text { var. thuringiensis }\end{array}$} & HD2 & $\mathrm{ND}^{d}$ & 9 & \multicolumn{6}{|c|}{$5.2,6.2,7.2,32,37,54,57,75,(150)$} & \\
\hline & $13 \mathrm{Al}$ & ND & ND & \multirow{3}{*}{\multicolumn{2}{|c|}{$2.4,3.4,80$}} & & & & & \\
\hline \multirow[t]{2}{*}{ B. sphaericus } & 2297 & + & 3 & & & & & & & \\
\hline & SSII-1 & ND & ND & & & & & & & \\
\hline
\end{tabular}

a HD500A and HD500B were isolated from HD500 and shown in Fig. 2.

b 4Q1-54, a sporeless and rifampicin-resistant mutant, did not produce the crystals.

c Molecular weight of plasmid DNA within parentheses was not confirmed on agarose gel electrophoresis.

d ND; not determined.

DNA from the $4 \mathrm{Q} 1$ strain showed that the strain contained a number of distinct DNA bands (Fig. 1). The configuration of DNA was determined by the two-dimensional gel electrophoresis of $0.4 \%$ or $0.5 \%$ agarose. Relative molecular weights of the plasmid DNAs were determined from a standard curve of authentic plasmids in $0.4 \%, 0.5 \%$, and $0.7 \%$ agarose gels. The 4Q1 strain has at least 7 distinct plasmid DNAs which were called pBTI-1, pBTI-2, pBTI-3, pBTI-4, pBTI-5, pBTI-6, and pBTI-7 in this report, which are $3.6 \mathrm{Md}, 4.3 \mathrm{Md}$, $4.9 \mathrm{Md}, 10.0 \mathrm{Md}, 63 \mathrm{Md}, 70 \mathrm{Md}$, and $82 \mathrm{Md}$, respectively (Table III). The plasmid DNAs were isolated at various times after inoculation and then the large plasmids (pBTI-5, pBTI-6, and pBTI-7) were easily detected at $20 \sim 25 \mathrm{hr}$ after inoculation (Fig. 1).

Plasmid patterns of various strains of B. thuringiensis and B. sphaericus

The plasmid DNA was analyzed by $0.5 \%$ agarose gel electrophoresis and the results are shown in Fig. 2. The number of plasmid bands detected in 4 strains (4Q1, HD563, HD648, and HD654) was 7. The HD500 strain used for the determination of the $\mathrm{LC}_{50}$ value was separated into HD500A and HD500B. The HD500A (crystalliferous) strain did not contain pBTI-3, and the HD500B (acrystalliferous) strain did not contain either pBTI-3 or pBTI-6. The 4Q1-54 strain did not have two 


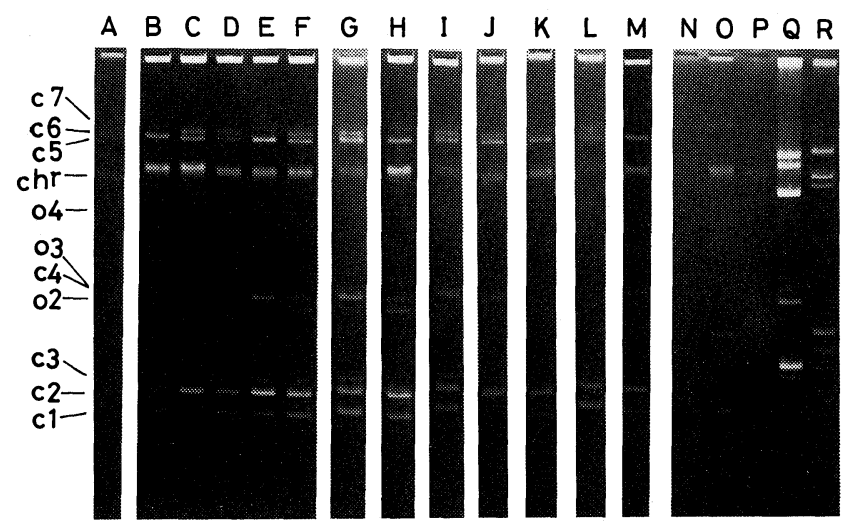

FIG. 2. Plasmid Patterns of Various Strains of B. thuringiensis and B. sphaericus.

The strains of $B$. thuringiensis var. israelensis HD500A (A), HD500B (B), HD522 (C), HD563 (D), HD567 (E), HD654 (F), HD648 (G), HD756 (H), 4Q1 (I), 4Q1-54 (J), 4Q4 (K), ONR60A (Bulla) (L), ONR60A (IPL) (M), B. sphaericus $1593(\mathrm{~N})$, B. sphaericus 2297 (O), B. sphaericus SSII-1 (P), B. thuringiensis var. kurstaki HD1 (Q) and $B$. thuringiensis var. thuringiensis $\mathrm{HD} 2(\mathrm{R})$ were cultured in PY broth medium at $30^{\circ} \mathrm{C}$ with shaking for $24 \mathrm{hr}$. Plasmid samples $(20 \mu \mathrm{l})$ were applied to slots on a $0.5 \%$ agarose slab gel and the electrophoresis was done by the procedures described in MATERIALS AND METHODS. The plasmids of HD1 and HD2 were shown as markers of molecular weight.

plasmids, pBTI-1 and pBTI-7, but contained pBTI-6. The 4Q1-54 strain was a rifampicinresistant mutant which lost the abilities of the delta-endotoxin crystal- and the sporeformation but had the insecticidal activity. All mutants derived from $4 \mathrm{Q} 1$, which lost the crystal-forming ability but had the plasmid pBTI-6, showed lower insecticidal activity than that of $4 \mathrm{Q} 1$, but a similar activity as kurstaki or $B$. sphaericus strains. The $B$. sphaericus strains, HD1, and HD2 did not contain the same plasmid as that in the israelensis strains. All israelensis strains lacking the plasmid pBTI-6 did not have the insecticidal activity. These results are listed in Table III. These results suggested that the insecticidal activity of the israelensis strains is associated with the plasmid pBTI-6 DNA.

\section{DISCUSSION}

The insecticidal activities of the purified crystal and crude samples of israelensis against mosquito larvae were measured. The activity of the purified crystals from the 4Q1 strain was about 330 times higher than that of a crude sample from the same strain, indicating that the insecticidal substance was about $0.3 \%$ of the crude sample. Also the amount of active substance was calculated as about $20 \%$ of dry matter in the crude sample. It is apparent that the active substance in dry matter is almost crystalline protein but not any other toxic substance like beta-exotoxin, because water insoluble materials were collected from the cell lysate. The plasmid patterns obtained from israelensis were shown by Iizuka et al. ${ }^{29)}$ but they did not discuss the correlation between a specific plasmid and the toxicity. Faust et al. ${ }^{181}$ suggested that loss of a specific plasmid $(4.0 \sim 4.4 \mathrm{Md})$ was associated with loss of the crystal production, while it was proposed by Kamdar and Jayaraman ${ }^{16)}$ that loss of both of the insecticidal activity and the crystal production was correlated to loss of a large plasmid and Ward and Ellar ${ }^{17)}$ showed that loss of the $72 \mathrm{Md}$ plasmid was invariably accompanied with loss of the ability to synthesize the insecticidal delta-endotoxin protein.

After this manuscript was submitted, González and Carlton $^{31)}$ reported the plasmid patterns of crystalliferous and acrystalliferous mutants of the HD567 strain and concluded that a $75 \mathrm{Md}$ transmissible plasmid was impli- 
cated in the crystal production. However the HD567 strain used in our experiments did not contain the $70 \mathrm{Md}$ (or $75 \mathrm{Md}$ ) plasmid, the crystal-forming activity and also the insecticidal materials. This contradiction might be due to the spontaneous loss of the $70 \mathrm{Md}$ plasmid by our HD567 strain.

This investigation has been performed independently from other investigators and the relationship between the $\mathrm{LC}_{50}$ values and the plasmid patterns of 12 israelensis strains is reported. Also in this report we showed that all strains carrying the insecticidal activity always contained the $70 \mathrm{Md}$ plasmid and suggested that the $70 \mathrm{Md}$ plasmid (pBTI-6) was required for their insecticidal activities, even in those israelensis strains which lost the crystalproducing ability.

Acknowledgments. Authors thank Drs T. Iizuka (Lab. Sericology, Hokkaido Univ.), T. Yamamoto (Cotton Insects Res., ARS, USDA, U.S.A.), and D. M. Ellis (Bacillus Genetic Stock Center, Ohio State Univ., U.S.A.) for their kind supply of several B. thuringiensis strains.

This investigation was supported in part by a Grant-inAid (No. 57560079) for Scientific Research from the Ministry of Education, Science and Culture of Japan.

\section{REFERENCES}

1) H. de Barjac, C. R. Acad. Sci. Paris, Ser. D, 286, 797 (1978).

2) A. H. Undeen and W. L. Nagel, Mosq. News, 38, 524 (1978).

3) D. J. Tyrell, L. A. Bulla, Jr., R. E. Andrews, Jr., K. J. Kramer, L. I. Davidson and P. Nordin, J. Bacteriol., 145, 1052 (1981).

4) D. J. Tyrell, L. I. Davidson, L. A. Bulla, Jr. and W. A. Ramoska, Appl. Environ. Microbiol., 38, 656 (1979).

5) M. S. Mulla, B. A. Federici, H. A. Darwazeh and L. Ede, Appl. Environ. Microbiol., 43, 1288 (1982).

6) J. M. González, Jr. and B. C. Carlton, Plasmid, 3, 92 (1980).

7) J. M. González, Jr., H. T. Dulmage and B. C. Carlton, Plasmid, 5, 351 (198i).

8) J. M. González, Jr., B. J. Brown and B. C. Carlton, Proc. Natl. Acad. Sci. U.S.A., 79, 6951 (1982).
9) H. E. Schnepf and H. R. Whiteley, Proc. Natl. Acad. Sci. U.S.A., 78, 2893 (1981).

10) G. A. Held, L. A. Bulla, Jr., E. Ferrari, J. Hoch, A. I. Aronson and S. A. Minnich, Proc. Natl. Acad. Sci. U.S.A., 79, 6065 (1982).

11) A. Klier, F. Fargette, J. Ribier and G. Rapoport, The EMBO Journal, 1, 791 (1982).

12) H. R. Whiteley, J. W. Kronstad, H. E. Schnepf and J. P. DesRosier, "Molecular Cloning and Gene Regulation in Bacilli," ed. by A. T. Ganesan, S. Chang and J. A. Hoch, Academic Press Inc., New York and London, 1982, pp. 131 144.

13) J. W. Kronstad, H. E. Schnepf and H. R. Whiteley, J. Bacteriol., 154, 419 (1983).

14) H. C. Wong, H. E. Schnepf and H. R. Whiteley, J. Biol. Chem., 258, 1960 (1983).

15) A. Klier, C. Parsot and G. Rapoport, Nucl. Acids Res., 11, 3973 (1983).

16) H. Kamdar and K. Jayaraman, Biochem. Biophys. Res. Commun., 110, 477 (1983).

17) E. S. Ward and D. J. Ellar, FEBS Lett., 158, 45 (1983).

18) R. M. Faust, K. Abe, G. A. Held, T. Iizuka, L. A. Bulla and C. L. Meyers, Plasmid, 9, 98 (1983).

19) K. Bernhard, H. Schrempf and W. Goebel, $J$. Bacreriol., 133, 897 (1978).

20) J. Nishiitsutsuji-Uwo, Y. Wakisaka and M. Eda, $J$. Invertebr. Pathol., 25, 355 (1975).

21) N. S. Goodman, R. J. Gottfried and M. H. Rogoff, $J$. Bacteriol., 94, 485 (1967).

22) R. W. Davis, D. Botstein and J. R. Roth, "A Manual for Genetic Engineering, Advanced Bacterial Genetics, Cold Spring Harbor Lab.," Cold Spring Harbor, New York, 1980, pp. 116 119.

23) H. C. Birnboim and J. Doly, Nucl. Acids Res., 7, 1513 (1979).

24) T. J. Gryczan and D. Dubnau, Proc. Natl. Acad. Sci. U.S.A., 75, 1428 (1978).

25) J. Kreft, K. Bernhard and W. Goebel, Mol. Gen. Genet., 162, 59 (1978).

26) G. Hintermann, H. M. Fischer, R. Crameri and R. Hütter, Plasmid, 5, 371 (1981).

27) T. Yamamoto and R. E. McLaughlin, Biochem. Biophys. Res. Commun., 103, 414 (1981).

28) W. Samasanti, S. Pantuwatana and A. Bhumiratana, J. Invertebr. Pathol., 39, 41 (1982).

29) T. Iizuka, R. M. Faust and R. S. Travers, J. Sericult. Sci. Japan, 50, 120 (1981).

30) A. A. Yousten and E. W. Davidson, Appl. Environ. Microbiol., 44, 1449 (1982).

31) J. M. González, Jr. and B. C. Carlton, Plasmid, 1128 (1984). 